\title{
STUDENTS' MASTERY OF PARTS OF SPEECH IN ENGLISH WRITING
}

\author{
Afief Fakhruddin \\ afief_sa@yahoo.com \\ Faculty of Teachers Training and Education Science \\ Universitas Majalengka
}

\begin{abstract}
The research is entitled "students' mastery of parts of speech (noun, pronoun, and verb) in English writing. The purposes of this research are (1) to find out the students' mastery of parts of speech (noun, pronoun and verb),(2) to find out the most and least understood parts of speech among noun, pronoun and verb often found in English writing,(3) to find outthe common problems faced by the students,(4). To find out workable solutions to these problems so as to increase the students' mastery in using parts of speech (noun, pronoun and verb) in English writing. The data collections are done by giving questionnaire, test in completion item and simple English writing. The conclusion of this research are: (1) the students' mastery of parts of speech is fair $(60,30),(2)$ the most understood parts of speech is Noun $(21,66 \%$ error) and the least understood parts of speech is Verb $(49,46 \%$ error), (3) common problems happened in constructing countable and uncountable noun, using possessive pronoun and pronoun function as object, and using full verb and to be in constructing continuous and future tense. (4) The workable solutions that can be used are by using game, and quiz.
\end{abstract}

Keywords: Students’ Mastery, Parts of Speech, English Writing.

\section{Background of the study}

Language is one of the instruments to communicate. People use language to state or express their feeling about certain things and to communicate each other. Webster Collegiate Dictionary in Alwasilah (1993) describes language as a systematic means of communicating ideas or feeling by the use of conventionalized signs, sounds, gestures or marks, which have meanings understood by the communicators. In other words, language serves as a means of communication that used to convey and express ideas, thought, wishes, feeling used by human being through communication.

Basically in learning English, there are four basic skills. They are speaking, reading, writing and listening. The four skills are related each other (Conkey, 1987). By mastering those skills, people will be able to communicate and interact well with the other people. Moreover, it will be beneficial if they master the other three elements of language i.e. structure, pronunciation, and vocabulary. 
Having a good mastery in English especially writing is one of every learner' aims in learning the language. It is the aim that is clearly stipulated in English teaching curriculum and it is embedded explicitly or implicitly in English teaching syllabi (Soehendro, 2006: vii) or even in the lesson plan that is brought into the classroom by English teachers when teaching certain topics of, say, English Grammar.

However, being a master of English, especially for Senior High School students, who are going to be the subject of this research, remains a utopian ideal, something unreachable in terms of school semester periods, yet in terms of years on which "truly English teaching learning process" does exist. This indicates on the other side that mastering English is not something impossible but something challenging. It likes the ability of Senior High School students where some of them in a higher level, and some others in a lower level of English.

Precisely, students' mastery of English will be generally viewed from four sides, mastery of listening, speaking, reading and writing (Soehendro, 2006: ix). But this research focuses on English writing with proper uses of good grammatical structure in this case noun, pronoun and verb.

The researcher interested to do research about students' mastery of parts of speech because parts of speech are basic English that is important to understand by foreign language learners. The research focuses to the three kinds of parts of speech (Noun, Pronoun and Verb) because the researcher emphasizes to English sentences that at least consists of subject and predicate. In this case, subject should be Noun or Pronoun, and the predicates include the verb.

To make a sound research, the research questions are formulated in such a systematic way that the research goes nowhere but answering the following questions:

1. How is the students' mastery of parts of speech (noun, pronoun and verb) in English writing?

2. What are the most and least understood parts of speech among noun, pronoun and verb often found in English writing?

3. What are the common problems faced by the students?

4. 'What are workable solutions to these problems so as to increase the students' mastery in using parts of speech (noun, pronoun and verb) in English writing?

\section{Literature Review}

\section{Students Mastery}

In summary as quoted by Davis \& Sorrel (1995) in Robinson (1992), "mastery learning is not a new method of instruction. It is based on the concept that all students can learn when provided with conditions appropriate to their situation. The student must reach a predetermined level of mastery on one unit before they are allowed to progress to the next. In a mastery learning setting, students are given specific feedback about their learning progress at regular 
intervals throughout the instructional period. This feedback helps students identify what they have learned well and what they have not learned well. Areas that were not learned well are allotted more time to achieve mastery. Only grades "A" and "B" are permitted because these are the accepted standards of mastery. Traditional instruction holds time constant and allows mastery to vary while mastery learning or systematic instruction holds mastery constant and allows time to vary.

From the explanation above, it can be summarized that students' mastery is the great skillfulness (the state of being cognitively skillful) and knowledge of some subject or activity of students that allow them to progress to the next level of learning activity.

The students' mastery relates to the problem face by the students. Before analyzing the data, the researcher describes the difference between mistake and error. Mistake and error have difference meaning. When the learner study foreign language, they sometimes make something wrong. That is what is so-called a mistake or an error.

Mistake is caused by performance factor. A mistake refers to a performance error that is either random or slip of the tongue, that is failure to utilize a known system correctly. For example: learners forget pronouncing certain sounds, words, spelling, or stress of words. When the learners make a mistake, they can correct automatically by themselves.

Error is caused by the competence factor. Error is systematic deviation when the learner has not yet learnt something and consistently gets it wrong. Meaning that learners have not understand yet the linguistic use of given language. Error can not be corrected easily and quickly. The teachers explain causes of error, so that they can revise their error, because learners don't realize that they have made error. The teacher can explain those causes of the errors, so they can refine that error.

Frank (1972:1) elaborates that the words that form the central core of the sentence-around which all the other word "cluster"- are the part of speech known as noun, pronoun and verb. The central core words are the parts of speech called adjective and adverb; the words that show a particular kind of connecting relationship between these four parts of speech are called prepositions and conjunctions. Thus, to make a central core in the sentence, the important thing that must be understood is noun, verb and pronoun as subject and predicate in the sentence. In this research, the part of speech focuses on the use of noun, pronoun and verb.

Frank (1972:6) points out that noun are one of the important parts of speech. It is an arrangement with the verb that helps to form the sentence core which is essential to every complete sentence. Hence, it can be concluded that noun is a class of word that refers to person or thing which functions as subject or object in the sentence.

Frank in Modern English (1972:6) explains that when classified by meaning some nouns may belong to more than one type of noun, such as proper noun, concrete or abstract noun, countable or uncountable noun and collective noun.

In this research the focus are on the use of countable and uncountable noun. According to Frank (1972:7), a countable noun can usually be made plural by the addition of $-\mathrm{s}$ (one girl, two girls). An uncountable noun is not used in the plural. Mass nouns form one type of uncountable noun. They are words for concrete 
objects stated in an undivided quality (coffee, iron). Abstract nouns (including names of school subject and sport) are non countable.Moreover, Thomson and Martinet (1986:28) explain that uncountable nouns are always singular and are not used with a/an:

I don't want (any) advice or help. I want (some) information.

He has had no experience in this sort of work.

These nouns are often preceded by some, any, no, a little etc, or by nouns such as bit, piece, slice.Azar (1999:107-108) states that a count or countable noun may be preceded by a/an in the singular and takes final $-\mathrm{s} /$-es in the plural for instance a chair, some chairs. Then, non count or uncountable noun is not immediately preceded by a/an and has no plural form, so it does not take a final s/-es such as furniture, some furniture. Moreover, Frank (1972:9-11) explains about four functions of noun as subject, complement, subjective complement and object complement. However, this research focuses on the function of noun as subject of verb and complement of verb.

1. Subject of verb

Who or what is being talked about. The verb agrees with the subject in the person (first, second, third) and in number (singular, plural). Example: The girl is resting.

2. Complement of verb

a. a direct object : who or what receives the action of verb

Example: We need some money

b. an indirect object : a second object to or for which the action of the verb is directed

Example: please give that man some money.

From the explanation above, it can be implied that noun is one kind of parts of speech that refers to someone or something that has function as subject or object in the sentence.

Frank (1972:20) states that pronoun makes up a small class of words of very high frequency. The traditional definition of a pronoun as a word that takes the place of noun is applicable to some types of pronoun but not others. So, pronoun is a class of word that refers to the previous noun that functions as subject or object in the sentence.

This research deals with the use of personal pronoun. Frank (1972:21) in Modern English elaborates that there are many types of personal pronouns such as:

$\square$ The speaker is called the first person.

Singular : I (spelled with a capital letter).

Plural : We (includes the speaker and one or more others)

$\square \square$ The person being spoken to is called the second person you (singular and plural).

$\square \square$ The person or thing being spoken of is called the third person.

Singular : He (for male), She (for female), It (for things also for live beings whose sex unknown or unimportant to the speaker).

Plural : They (for all live beings and for all things).

According to Thomson and Martinet (1986:79), I and you are more common in ordinary conversation. It is a more "friendly" pronoun and implies that the speaker can imagine himself in such a position. While, Azar (2005:134) mentions 
that in the use of he or she the pronoun refers to particular individuals whose gender is known. The nouns are not generic. For instance, a student walked into the room. He/She was looking for the teacher. A generic noun does not represent to any person or thing in particular; rather it represents a whole group. With the generic noun, a singular masculine pronoun has been used traditionally, but many English speakers use both masculine and feminine pronouns to refer to a singular generic noun.Frank (1972:48) further explains about predicating and linking verb. A predicating verb is the chief word in the predicate that say something about subject. The predicating word (or predicator) has traditionally been called a verb of "action" (babies cry; she wrote a letter), but has actually been interpreted to include most non-action verbs that are not linking verb (for example, I remember him; She needs more money).

A linking verb is a verb of incomplete predication; it is merely announces that the real predicate follow. The important word in complement is usually an adjective (The girl is pretty) or a noun (She is a pretty girl). The -ly adverb of manner (quickly, angrily) are not used with linking verb. The more common linking verb are appear, be, become, get (in the sense of become), look, remain, seem.

Frank (1972:52) adds that the grammatical form of verbs is usually discussed in connection with tense. The description of verbs forms differs according to the way the term tense is interpreted. The most common interpretation of tense is a semantic one; each tense roughly indicates a kind of time.

The second interpretation of tense is based on the form of the verb alone. Based on this interpretation, there are only two tenses, a present and a past - each of which is marked by different forms in the lexical verbs itself or in the auxiliary used with it.The elaborate explanation about the use of tenses is shown below (Frank, 1972:68-75)

$\checkmark$ Use of the simple present tense.

1. To express general time

In such a use, the simple present is usually "timeless". It has no terminal points in time - it can include past, present and future. Such general statements may range all the way from eternal truths to generalizations about the costumes of single individuals. For example: The earth revolves around the sun

2. To express present time

The simple present indicates present time with many non action verbs, especially those expressing states or condition. For example: She seems to be very tired today.

3. To express future times

With verb like come, go, arrive, and depart. A future time expression is usually required.(I arrive in Hong Kong on Saturday.). With verb are used in time clause or conditional clause. (He will take a vacation in Europe after he graduates from collage.). With verb are used for terse announcements of schedule event or for making proclamation. (Our club gives its annual dinner next week.). With verbs of saying and telling. For example: He says that he can not come tonight.

Use of the present progressive Tense (Continuous tense)

This tense is used for single temporary event that has a beginning and an end. This form suggests that an event began and is continuing, but it does not necessarily include the end of the action. Example: The play is beginning (or 
ending) now. Because of its ability to suggest action in progress, the progressive form often conveys greater vividness, emotion, or emphasis the non progressive form does like in sentence "We reach the like just as the sun was sitting."

The present progressive tense generally indicates that the future action is a part of a plan made in the present, with the past possibly included. It is used frequently used with verb that can show the intention of the subject or that can indicate the result of planning by some agent. For instance, I'm giving a party tomorrow.Furthermore, Harmer (2004: 12) argues that writing is used for a wide variety of purposes. It is produced in many different forms. A consideration of the writing process and of how spelling and writing are related each other, especially in a world of changing communication media-is not only for academic interest. For many years, the teaching of writing focused on the written product rather than on the writing process. Product approaches expected the student to analyze text in term of what language they used and how they construct.

Writing (as one of four skills of listening, speaking, reading and writing) has always formed parts of the syllabus in the teaching of English. However, it can be used for a variety of purposes, ranging from being merely a 'backup' for grammar teaching to a major syllabus strand in its own right, where mastering the ability to write effectively as a key objective for learning. (Harmer, 2004:31)

It can be concluded that writing encourage students to focus on accurate language use and because they think as they write, it may well provoke language development as they resolve problems which the writing puts into their mind.

\section{Method of the Research}

This research used descriptive quantitative method. Quantitative research comprises every kind of research due to percentage, average and other statistic operation. Related to descriptive method, Ary et.al (1972:26) states that descriptive research describes and interprets what is. It is concerned with condition or relationship that exists; practices that prevail, beliefs, point of view or attitudes that are held, processes that are going on; effect that are being felt; or trends that are developing. Its major purpose is to tell "what is". A case study is one kind of descriptive research

The case study is a method of choice when the phenomenon under study is not readily distinguishable from its content. The purpose of such observation is to probe deeply and to analyze intensively the multifarious phenomena that constitute the life cycle of the unit with a view to establish generalizations about the wider population to which that unit belongs (Blaxter et.al, 2006:71).

Based on the theory above, the researcher makes a conclusion that descriptive quantitative method is suitable to be used in this research because it is suitable with the purpose of the research, that is to get description about student mastery of parts of speech focusing on the use of noun, pronoun and verb in English writing. Population is defined as all members of any well-defined class of people, events or objects ( Ary et.al, 1972:162)

Population in this research was the second semester two students of English department. The number of population is 23 students.

Sample is a portion of a population (Ary et.al, 1972:162). The technique that the researcher uses is purpsive sampling. 


\section{Data Validation}

Validity and reliability are essential to the effectiveness of any data gathering procedures to get the data to be valid and reliable, the instrument should be measured based on:

Validity of the instrument

Validity is an indispensable characteristic of measuring devices. Educational testing instrument ordinarily consists of a number of tasks that are put together by test makers for the purpose of appraising complex qualities such as achievement, intelligence, creativity, aptitude and attitude. The items in the tests are designed to serve as indicator of these construct (Ary et.al, 1972:191). An instrument is valid, if it can measure what it should measure, and investigate data from observed variable opportunity (Hughes, 1989:22).

The formula of Pearson Product moment is as follows (Arikunto, 2006: 170):

$$
\mathrm{r}_{\mathrm{xy}}=\frac{N \sum X Y-\left(\sum X\right)\left(\sum Y\right)}{\sqrt{\left\{N \sum X^{2}-\left(\sum X^{2}\right)\right\}\left\{N \sum Y^{2}-\left(\sum Y^{2}\right)\right\}}}
$$

Where:

rxy $=$ correlation coefficient

$\mathrm{N} \quad=$ number of student

$\mathrm{X} \quad=$ statement score

$\mathrm{Y} \quad=$ total scores

$\mathrm{XY} \quad=$ statement score multiplies total score.

Criterion:

1. If rxy value > rtable value, so the indicators are valid.

2. If rxy value $\leq$ rtable value, so the indicators are not valid.

In this research, the researcher used a logical validity, such as content validity, face validity, and construct validity.

In this research, the researcher used a logical validity, such as content validity, face validity, and construct validity.

1. Content validity

The researcher chose content validity to measure the validity level of an instrument. Content validity refers to the degree to which a test sample represents the content area which is to be measured. This is the type of validity that educators are most concerned with. In the examination prepared by teachers to measure their students' mastery of subject matter, this type of validity is of primary importance. (Ary .et.al, 1972:191). The test maker may ask a number of experts to examine the items systematically and indicate whether or not they represent sufficiently the theoretical universe from which they are drawn. 
In order to make the content of this test valid, the researcher asked the teacher about the material that has been taught. So in giving the test, the researcher would not deviate from the taught materials.

Reliability of the instrument.

Reliability of a measuring instrument is the degree of consistency with which it measures what ever it is meaning (Ary et.al, 1972:200). To ensure the test is reliable or not, the researcher used re-tests using the formula of Alfa Cronbach as follows:

$$
\mathrm{ri}=\left(\frac{k}{k-1}\right)\left(1-\frac{\sum S i^{2}}{S t^{2}}\right)
$$

Where:

$$
\begin{aligned}
\mathrm{ri} & =\text { instrument validity } \\
\mathrm{k} & =\text { quadrate mean between subject } \\
& =\text { error mean quadrate } \\
& =\text { total variants }
\end{aligned}
$$

\section{Criterion:}

1. If ri count value $>$ ritable, so the indicators are reliable.

2. If ricount value $\leq$ ri table, so the indicators are not reliable.

Technique of Data Analysis

After the data were collected, an analysis was conducted. The data analysis was done through four steps:

1. Data Arrangement

Data from the test were collected to check if all data were available. The data arrangement that had to be chosen had to have relation with the research.

2. Data Classification

Data classification is the way to classify the data based on the certain classification, to make the data analysis easier.

3. Data Analysis

Data analysis is done to test the research based on the research problem.

a. Scoring the students' answer of the test

In this research, the formula for measuring students' individual ability in using parts of speech in completion items is as follows (Ali, 1985:184):

$$
\mathrm{P}=\frac{F}{N} \quad \mathrm{X} 100 \%
$$

Notes:

$\mathrm{P} \quad$ : the percentage of the correct answer

$\mathrm{F} \quad$ : the frequency of the correct answer

$\mathrm{N} \quad$ : the total score of the number of item

Scoring the writing skill based on the scales below (Heaton, 1988:146):

Content 


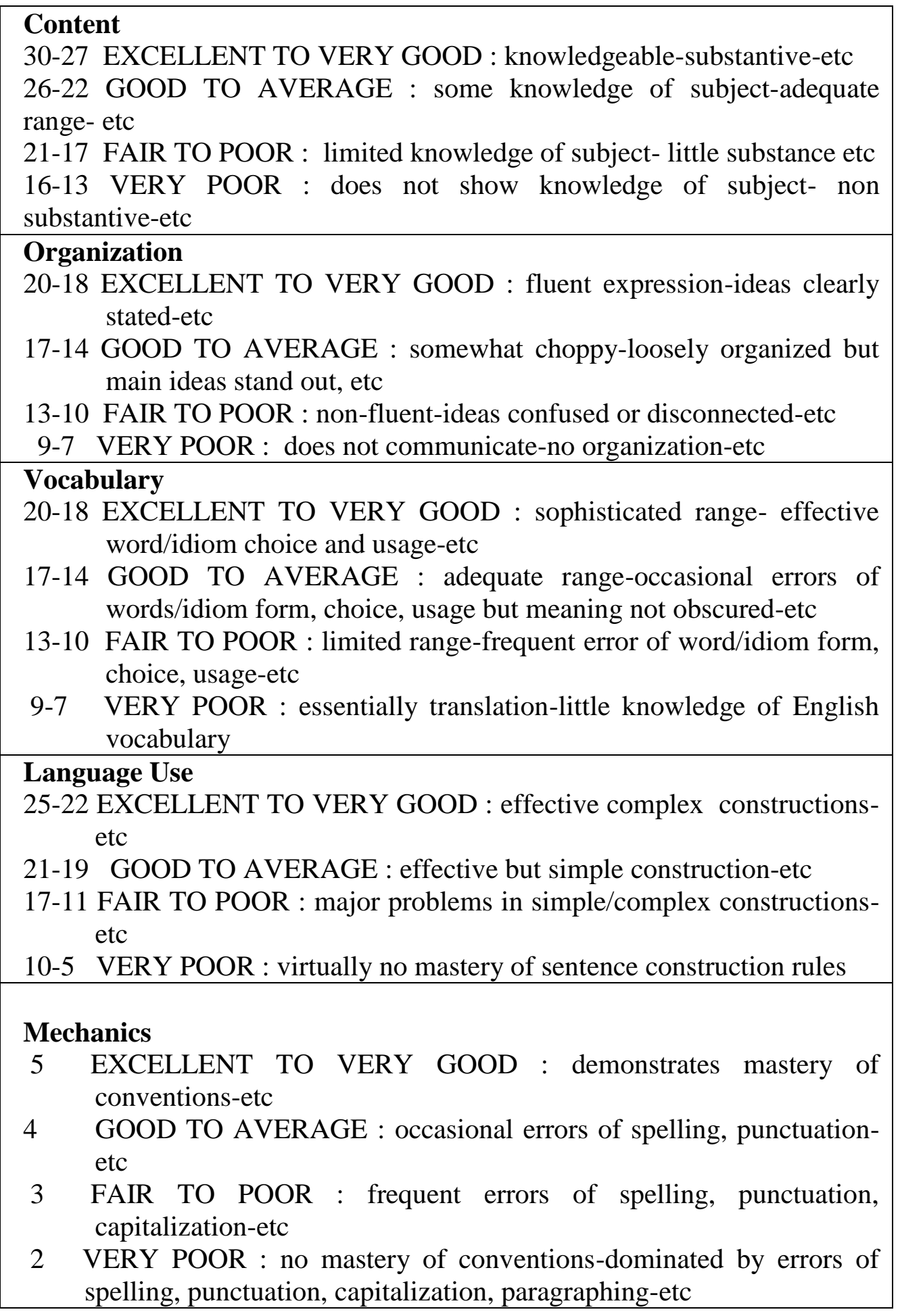

\section{Result and discussion.}

There were some steps for data analysis. The first step was to analyze the students' mastery of parts of speech one by one. Every sentence was analyzed, including noun, pronoun and verb. In analyzing the data to get the description about students' mastery of parts of speech, the researcher computed the data by using the following steps: 


\section{Measuring the student individual ability.}

According to Arikunto (2006:44), 86,67\% is categorized into very good. Therefore, it means that the ability of the sample number 1 is very good.

It was found that 2 students who got very good score since they could answer $81 \%-100 \%$ of the total questions, 12 students got good scores since they could answer $61 \%-80 \%$ of the total questions, 16 students got fair score since they could answer $41 \%-60 \%$ of the total questions, 2 students got poor scores since they could answer $21 \%-40 \%$ of the total questions.

\begin{tabular}{|c|c|c|c|}
\hline SCORES $(\%)$ & CRITERION & FREQUENCY & PRESENTAGE \\
\hline $81-100$ & VERY GOOD & 2 & $6,45 \%$ \\
\hline $61-80$ & GOOD & 12 & $38,71 \%$ \\
& & & $51,61 \%$ \\
\hline $41-60$ & FAIR & 16 & $3,23 \%$ \\
\hline $21-40$ & POOR & 1 & 0 \\
\hline $0-20$ & VERY POOR & 0 & \\
\hline
\end{tabular}

Based on the result in the table above, it was found that 2 students who got very good score since they could answer $81 \%-100 \%$ of the total questions, 12 students got good scores since they could answer $61 \%-80 \%$ of the total questions, 16 students got fair score since they could answer $41 \%-60 \%$ of the total questions, 2 students got poor scores since they could answer $21 \%-40 \%$ of the total questions.

It was shown that the number of students who had the ability in using parts of speech was 30 students (those whose scores belong to very good, good, and fair) or $93,55 \%$ of the total sample. From the table, it could be seen that majority of the students had an average mastery of parts of speech, about $51,61 \%$ of the students had fair mastery and only 3,23\% of them who still found the difficulties to learn parts of speech.of the students had an average mastery of parts of speech, about $51,61 \%$ of the students had fair mastery and only 3,23\% of them who still found the difficulties to learn parts of speech.

Moreover, from the table, each level of the students' mastery of parts of speech can be clearly understood. Then, number of students along with their categories will be drawn into a diagram as follows:

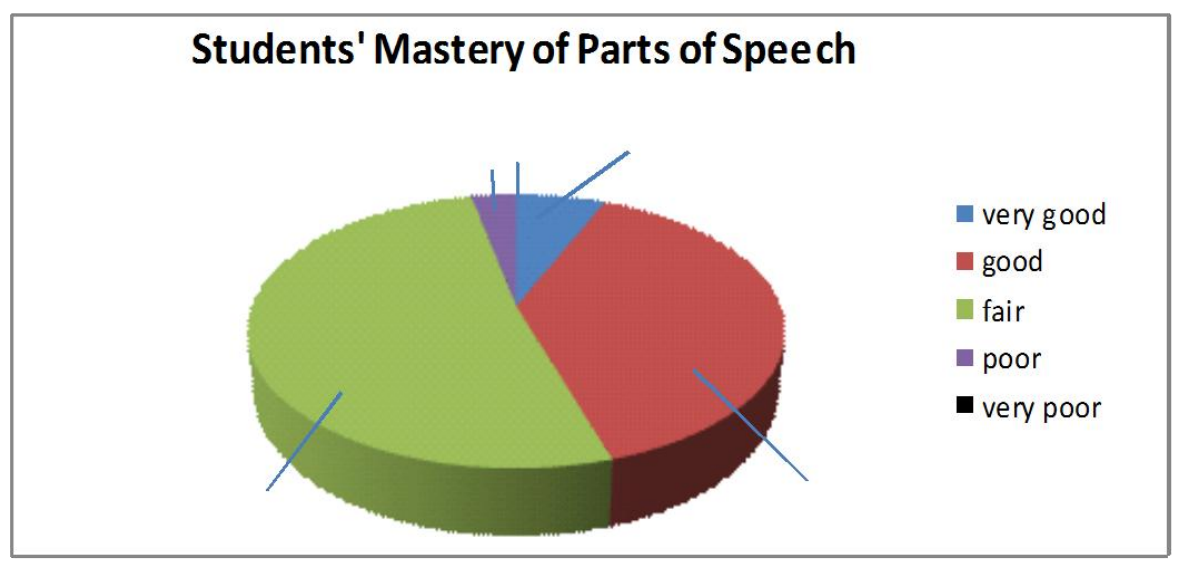


From the chart, it can be described that most of the students had fair mastery of part of speech. It was around $51,61 \%$ students that had fair mastery. Then, $38,71 \%$ students had good mastery, $6,45 \%$ students had very good mastery and $3,23 \%$ students had poor mastery of parts of speech. It means that most of the students have understood parts of speech, although some of them still faced difficulty.

\section{The most and the least understood parts of speech.}

The most understood parts of speech was Noun because there was $21.66 \%$ errors made by the students in using Noun in the sentences. Then, the least understood parts of speech was Verb, because there is $49,46 \%$ errors that is made by the students in using verb in the sentences. It means that the students still had the most difficulties in understanding and using Verb in the sentences.

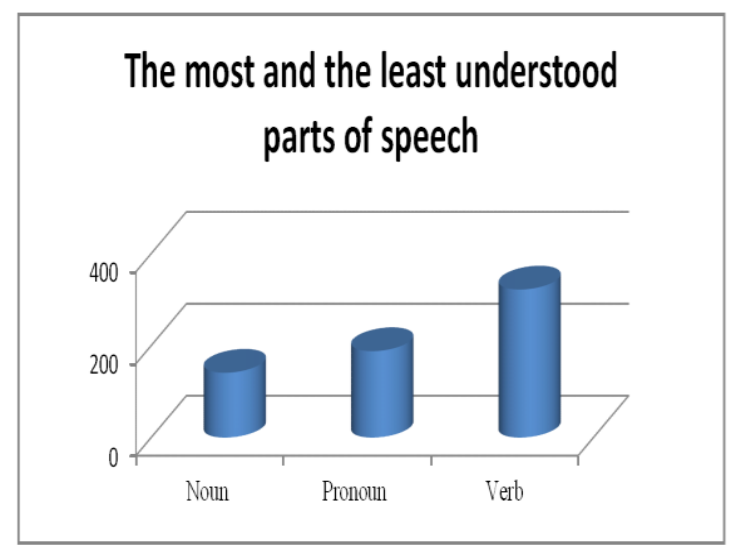

The chart above describes that the most understood parts of speech (among noun, pronoun and verb) was Noun. It was gained from 141 errors that were made by the students. Then, about 188 errors happened in pronoun form and the least understood parts of speech were Verb because the students made 322 errors in using parts of speech. So, it could be concluded that most of the students had the biggest problems in understanding Verb compared to the other parts of speech (noun and pronoun).

\section{The common problems}

There were some problems faced by the students in understanding and using parts of speech (Noun, Pronoun, and Verb) in English writing.There are many common problems found in the completion items and students writing.

Noun Category
\begin{tabular}{|l|l|}
\hline Incorrect answer & Correct answer \\
\hline Two kilogram of egg & Two kilograms of eggs \\
One kilogram pineapple & One kilogram of pineapples \\
For two year & For two years \\
Many island & Many islands \\
Two kilogram tomato & Two kilograms of tomatoes \\
I have a lot of a hobby & Many hobbies \\
I have some hobby & Some hobbies \\
\hline
\end{tabular}


From the table above, it can be seen that the students still faced difficulty in making the plural form of countable noun. The plural form of countable noun should be added by -s/-es/-ies. For instance, in the word, Island has plural form with added $-\mathrm{s}$ become many islands. Then, for the plural form of hobby, the word should be added by -ies become many hobbies. And the last, the plural form of tomato should be added by -es become two kilograms of tomatoes.

\section{Pronoun Category}

\begin{tabular}{|c|c|}
\hline Incorrect answer & Correct answer \\
\hline $\begin{array}{l}\text { - The book is very interesting. It's } \\
\text { tells about journey adventure in the } \\
\text { Amazon forest. } \\
\text { - Bali is one of popular tourist resort } \\
\text { in Indonesia. Many foreign tourist } \\
\text { come to visit this. } \\
\text { - Alan invites me to come to him } \\
\text { house tonight for dinner. } \\
\text { - Jane left it's book on my desk. So, I } \\
\text { will return its to her } \\
\text { - He is my foot ball idol because of } \\
\text { he skills } \\
\text { - My name is Romero. His full name } \\
\text { is Slamet Romero } \\
\text { - I am school is in SMA Yos } \\
\text { Sudarso }\end{array}$ & $\begin{array}{l}\text { - The book is very interesting. It } \\
\text { tells about journey adventure in } \\
\text { the Amazon forest. } \\
\text { - Bali is one of popular tourist } \\
\text { resort in Indonesia. Many foreign } \\
\text { tourist come to visit it. } \\
\text { - Alan invites me to come to his } \\
\text { house tonight for dinner } \\
\text { - Jane left her book on my desk. } \\
\text { - So, I will return it to her. } \\
\text { He is my foot ball idol because of } \\
\text { his skills } \\
\text { My name is Romero. My full } \\
\text { name is Slamet Romero } \\
\text { My school is SMA Yos Sudarso }\end{array}$ \\
\hline
\end{tabular}

that students were still confused to identify the function of each pronoun used as subject, object or possessive form. For instance, in sentence "Alan invites me to come to him house tonight for dinner". The sentence is false because the sentence needs pronoun that functions as possessive refers to Alan (boy). So the pronoun that suitable with this sentence is "his" and the sentence become "Alan invites me to come to his house tonight for dinner".

In other sentence "Bali is one of popular tourist resort in Indonesia. Many foreign tourists come to visitthis" is also false because that sentence needs pronoun as object that refer to thing (Bali), so the suitable pronoun in this sentence is "it" and the sentence become "Bali is one of popular tourist resort in Indonesia. Many foreign tourists come to visit it." 
Verb Category

\begin{tabular}{|c|c|}
\hline 11 & wer \\
\hline $\begin{array}{l}\text { I am like listening music } \\
\text { - I love foot ball but I is the next } \\
\text { Thierry Henry } \\
\text { I can told of my self } \\
\text { - I like fishing very much. I have it } \\
\text { every month } \\
\text { - I am to sense happy the moment I to } \\
\text { water flower } \\
\text { - I can to play with butterfly and } \\
\text { bumble bee } \\
\text { - I usually swimming with my friends } \\
\text { or my parents } \\
\text { - Do you know? I am still have my } \\
\text { other hobby } \\
\text { - Many children goes to the park and } \\
\text { plays football. } \\
\text { - We can knowledge } \\
\text { - She is a letter to her friend in } \\
\text { Bandung. } \\
\text { - He play basket ball with his friends. } \\
\text { - He only need some information. } \\
\text { - He eat a piece of banana cake and } \\
\text { drink a cup of milk for his } \\
\text { breakfast. } \\
\text { - That matter is make my body very } \\
\text { big Everyday, I and my friends go to } \\
\text { playing football }\end{array}$ & $\begin{array}{l}\text { - I am a senior high school } \\
\text { student } \\
\text { I like listening to music } \\
\text { - I love football and I will be the } \\
\text { next Thierry Henry } \\
\text { I can tell it by my self } \\
\text { - I like fishing very much. I do it } \\
\text { every month } \\
\text { - I felt happy when watering } \\
\text { flower } \\
\text { - I can play with butterfly and } \\
\text { bumble bee } \\
\text { - I usually swim with my friends } \\
\text { or my parents } \\
\text { - Do you know? I still have } \\
\text { another hobby } \\
\text { - Many children go to the park } \\
\text { and play football. } \\
\text { - We can get knowledge } \\
\text { - She writes a letter to her friend } \\
\text { in Bandung. } \\
\text { - He plays basket ball with his } \\
\text { friends. } \\
\text { - He only needs } \\
\text { information. } \\
\text { - He eats a piece of banana cake } \\
\text { and drinks a cup of milk for } \\
\text { - This breakfast. } \\
\text { - Every big matter makes my body } \\
\text { foot ball } \\
\text { - } \\
\text { - } \\
\text { - } \\
\text { - }\end{array}$ \\
\hline
\end{tabular}

the students still felt difficult to understanding about the use of to be (linking verb) and full verb (predicating verb). To be should be used in the sentence that needs complement while full verb should be used in the sentence that needs object. For instance, in sentence "I am a student is senior high school". The sentence is false because there are two verbs in the sentence, but it is right if that sentence needs to be as verb. Compare it with this sentence "She is a letter to her friend in Bandung", it is also false because that sentence needs full verb because of the object. The right sentence should be: She writes a letter to her friends in Bandung. The verb "write" is added by $-\mathrm{s}$ because the subject is the thirds person, when the third person singular is used (he, she, it), the verb must be added by $-\mathrm{s} /$-es./-ies but the first, second and third person plural (I, You, We, They) , e/-es/-ies are not added to the verb. 


\section{The workable solution}

The problems were found. There were some solutions that could be used to increase the students' mastery in using parts of speech (noun, pronoun and verb) in English writing.

the researchers proposed some workable solutions to these problems in order to increase the students' mastery of parts of speech as below:

\section{Game}

Games always become something that is favored by the children; including the senior high school students. The game was recommended to be used in class session within the learning process in order to be able to use and understand English grammar and parts of speech. There are many games that can be used to improve the students' mastery of parts of speech in English writing such as puzzle, crossword and so on.

\section{Quiz}

Sometimes, quiz would stimulate the spirit of the students to study hard. That was asking the students to follow the quiz after the learning was finished. It was aimed to measure the students understanding about the material. So, it could help review the given material before the lecture continued the lesson.

\section{Conclusion}

After conducting the research and analyzing the result of the research, it can be concluded that students' mastery of parts of speech in semester 2 students, as a follows:

The students' mastery of parts of speech was fair because there were $48.4 \%$ of the students who had fair mastery. The score of students was calculated and the result was the normal distribution. It means than the number of the student that have score under fifty is almost same with the number of students that have score above fifty. Then the most understood part of speech in this research was Noun because there were only $21.66 \%$ of the errors found in the students' writing and the least understood part of speech was Verb because there were $49.46 \%$ of the errors found in the students' writing. The workable solution that can be used to improve the student's mastery was by making the learning process more interesting for the students such as using game, and quiz. 


\section{REFERENCES}

Ali, M.(1985).Penelitian Kependidikan Prosedur dan Strategi.Bandung:Angkasa Alwasilah, A.C.(1993).Linguistik Suatu Pengantar.Bandung: Angkasa Arikunto,S.(2005).Managemenn Penelitian.Jakarta:Rineka Cipta Arikunto,S.(2006).ProsedurPenelitian:Suatu Pendekatan Praktek. Jakarta: Rineka Cipta

Ary, D, Lucy CJ and Asghar.(1972).Introduction to Reseach in Education.New York:Holt,Rinehart and Winston, Inc

Azar, B.S. (2005).Understanding and Using English Grammar.Jakarta barat:Bina Rupa Angkasa

Blaxter, L, Christina,H \&Mandcolm,T.(2006).How To Research.New York:Open University Press

Brown, JD. (1996). Testing in Language Program.New Jersey:Prentise Hall,inc Conkey,M.R.(1987).Definition of Learnoing.New York.Retrieved on 13 December 2008 available at http://www.mexico-child- link.org/

Davis \& Sorrel.(1995). Students' mastery.available at www.wikipedia.com retrieved on October, 21, 2009 at 11.00 a.m).

Frank, M.(1972).Modern English;A Practical Reference Guide.New Jersey: Prentice-Hall.

Harmer, Jeremy.(2004). How to Teach Writing. England: Pearson Education Ltd Heaton, J.B.(1988). Writing English language Tests.New York:Longman Inc.

Hornby, AS.(2000).Oxford Advance Learner's Dictionary of Current English.Oxford:Oxford University

Huges, Arthur. (1989). Testing for Language Teacher. New York: Cambrige University Press. 
Robinson, (1992). Students' mastery.available at www.wikipedia.com retrieved on October, 21, 2009 at 11.00 a.m).

Students' mastery. retrieved on on October, 21, 2009 at 11.00 a.m). available at $<$ ahref="http://www.thefreedictionary.com/mastery">mastery $</ a>$

Soehendro, B.(2006). Silabus Bahasa Inggris. Jakarta:Badan Standar Nasional Pendidikan

Tarigan, HG \& Tarigan J. (1995). Pengajaran Analisis kesalahan berbahasa. Bandung :Angkasa.

Thomson,A.J,\&.MartinetA.V.(1986).APracticalEnglishGrammar.Oxford:Oxford University Press. 